\title{
Correction to: Lunar Orbiter Photographic Atlas of the Near Side of the Moon
}

\section{Charles J. Byrne}

\section{Correction to:}

C. J. Byrne, Lunar Orbiter Photographic Atlas of the Near Side of the Moon, https://doi.org/10.1007/978-1-84628-154-9

The original version of the book was revised. CD-ROM and CD-ROM Logo was included in the book earlier and this has been replaced and can now be accessed at http://extras.springer.com/.

The corrections to this book are available at https://doi.org/10.1007/978-1-84628-154-9

The updated online version of this book can be found at https://doi.org/10.1007/978-1-84628-154-9 